\title{
Age-Related Atrophy
}

National Cancer Institute

\section{Source}

National Cancer Institute. Age-Related Atrophy. NCI Thesaurus. Code C97044.

Atrophy of the nervous system tissues and/or muscle tissues that is related to aging. 